Justine Alsop

\title{
Losing our minds \\ The impact of technology on reading and reflection
}

$\mathrm{L}$ ately I have been plagued by the thought that our society and, in particular, our universities are losing something intangible but very important-slowly and insidiously, our capacity for reflection is slipping away. My concern began when I read a book about roses, and a chapter described the beautiful, secluded gardens created for repose and reflection in the colleges of Oxford, and it intensified with the recent flush of publications on stress and the disappearance of time in modern life. ${ }^{1}$ There seems to be a great deal of concern surfacing about the effects that stress, technology, and multitasking are having on our souls and on our collective intellect.

You may be surprised to learn that I am relatively young and belong to that generation that is generally assumed to embrace all the gifts and challenges of technology. But the truth is, I have always been suspicious of technology and what is lost when things are made faster and easier. To me at least, it seems no coincidence that people seem more unhappy and confused than ever at a time when technology is supposed to be reducing complexity and making our lives easier.

\section{The loss of contemplation}

How does this relate to the academic library? Reading and contemplation has been a tradition of the university culture for hundreds of years. Heather Menzies' (Carleton University) recent survey of faculty members indicates that about 70 percent of professors report that they no longer read as deeply, reflectively, or as broadly as they once did. Quick scanning has replaced the slower, contemplative mode of reading. ${ }^{2}$ Amanda Cain's 2002 article entitled "Archimedes, reading, and the sustenance of academic research culture in library instruction" raised essential points about the importance of reading books as a "powerful psychic framework for scholarship." ${ }^{3}$

Students are also reading more haphazardly, if at all, while juggling part-time jobs and heavy courseloads. How many librarians have heard the frantic line, "I need to find 5 articles on this topic by tomorrow"? I think to myself, does the student care about this topic? Will she even read and reflect on these? Add to these trends the increasingly complex realm of new databases, and it is not surprising to realize students and faculty end up "Google-izing" their research. I think it is worrying that students and even faculty members are losing the time and the capacity to engage with their disciplines through reflecting on what they read and drawing together ideas from wide-ranging sources.

Our society also seems to be losing the spirited interchange of ideas that once characterized the university. Conversations are increasingly occurring over e-mail rather than face-to-face-what gestures and spontaneous thoughts are lost when we cease to communicate in one another's presence?

As librarians, are we losing the same capacity for reflection and communication? These trends are alarming to me and, while I cannot imagine a world without computers, e-mail, or electronic databases, I feel that we need to be looking more closely at what we

Justine Alsop is humanities and social sciences librarian at Brock University, e-mail: jalsop@brocku.ca

(c) 2005 Justine Alsop 
are losing. Certainly, I am not the first librarian to worry about the detrimental effects of technology and our increasingly rushed society and, like those before me, I grapple with how to find balance.

\section{Paring down instruction}

I have changed my approach to library instruction by paring things down, instructing students about how to use one database as opposed to three. I encourage students to find one or two good books on a topic and really read them and think about them. I plan on meeting with faculty and students in person now as opposed to through e-mail because I wonder what serendipitous moments I may miss when I simply type and click "send."

We can never return to the idealized world of academia in which students could wander along a riverbed with a book of poetry, a world immortalized in films such as Shadowlands or Brideshead Revisited, and nor would we necessarily want to. And yet I still look to the past wistfully, wishing that the academic library could still be a place where students gathered books and read them deeply and thoughtfully, instead of quickly downloading articles from their dorm rooms.

For my undergraduate degree, I was fortunate enough to attend a small university of small class sizes and devoted professors, and my experience was, in many ways, one of deep reading and engagement. The library's primary resource was books, and the professors still had the time to meet with me to discuss research and even host parties for the small student population. Browsing the shelves was my main research strategy and, while my colleagues might shudder, it was manageable! I did well in my studies and was able to pursue a master's degree in my discipline.

As academic librarians, I feel that we should address the issues around reading and reflection as thoroughly as we have addressed information literacy; indeed, the two concepts are interrelated. The recent flourish of research on stress and its subsequent effects on students and faculty should encourage

reflection on our part and perhaps a reassessment in the ways in which we provide library instruction and how we interact with our patrons.

"One thing is certain," writes Diane Ackerman, in her 2004 book An Alchemy of Mind, "memory suffers when we're under stress. Both stress and tedium can kill brain cells." As humans, a bit of stress can be a good thing-we need to be challenged and engaged; but, in the same, we have a vital need for quiet reflection, the opportunity to make sense of what we take in through our senses and through our research. What we are at the risk of losing is frightening: our relationships, intellectual abilities, and even our memories.

\section{Notes}

1. Carl Honoré's In Praise of Slow [Knopf, 2004], Heather Menzie's No Time [Douglas \& Macintyre, 2005], and Thomas Hylland

(continued on page 838)

\section{Focus on $50+$}

\section{AARP's \\ Ageline \\ Database}

Social gerontology \& aging-related research, policy, and practice

FREE searching at: www.aarp.org/ageline

Also available on CSA, Dialog, EBSCOhost, Ovid, a SilverPlatter agelinewarp.org

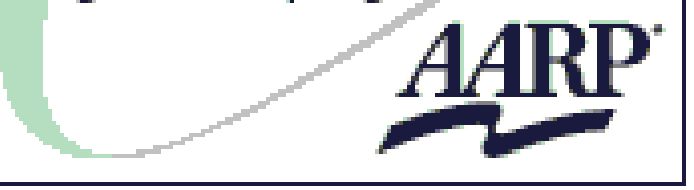


("L4osing our minds" continued from page Eriksen's The Tyranny of the Moment [UBC Press, 2001], to name a few).

2. Heather Menzies, (2005, May 1) "Dumbed down on campus, bit by bit," The Toronto Star p.D1, D12

3. Amanda Cain, (2002) "Archimedes, reading, and the sustenance of academic research culture in library instruction," Journal of Academic Librarianship, 28 (3): 115-121.

4. Diane Ackerman (2004), An Alchemy of Mind (New York: Scribner). $n$ 